\title{
An Analysis of Cultural and Psycho-social Problems Experienced by Students of Afghanistan Citizenship Studying in Turkey
}

\author{
Hafız BEK \\ Education Faculty, Uşak University, Uşak, 0064, Turkey
}

Copyright $\bigcirc 2018$ by authors, all rights reserved. Authors agree that this article remains permanently open access under the terms of the Creative Commons Attribution License 4.0 International License

\begin{abstract}
The purpose of this study is to determine the cultural and psycho-social problems experienced by students of Afghanistan citizenship studying at different faculties of a university in Turkey. With this purpose, human affairs were examined under the titles of accommodation and food, clothing, psychological and social affairs. The sample of the study consisted of 10 students of Afghanistan citizenship studying at Uşak University in the academic year of 2015-2016. The data collection tool of the study was a semi-structured interview form. The questions were determined by the researcher by receiving expert opinion. The method of descriptive analysis was used to analyze the data. As a result of the study, it was found that most of the students with Afghanistan citizenship did not experience significant problems in terms of communication and social issues; however, they experienced issues in terms of accommodation, food, clothing and psychological affairs.
\end{abstract}

Keywords University, Afghan Citizen, Cultural, Psycho-social

\section{Introduction}

We see that Afghanistan has been struggling with war for years. Therefore, as the government of the country is not able to provide their youth with sufficient services and opportunities of education, these youths usually resort to visiting other countries to receive better education and have a profession. It is seen that Turkey is at the top among the countries preferred for education by Afghan youths. Based on the report on students with foreign nationalities who are receiving scholarships published by the Ministry of National Education [1] for the academic year of 2015-16, 2949 students of Afghanistan citizenship attended different universities in Turkey for language preparation, undergraduate, master's and doctoral degrees. We may state that Turkey is at the top among the preferences of these young people as Turkey and Afghanistan are friendly countries on an international level with good relationships and they are culturally similar. After the Republic of Turkey was established and announced, it ratified a treaty of friendship with Afghanistan on 1 March 1921. In this treaty, in order to strengthen the relations, Turkey accepted to improve economic and commercial relations, send army officers and teachers in terms of cultural development $[2,3]$ and the relations between these countries, especially those related to education, have increasingly become prevalent since this date.

In recent years, Turkey has become a center of attraction for students coming from especially Turkic countries and neighboring countries with regards to the education sector as in other sectors. The reasons for students coming from these countries to prefer Turkey may be listed as the familiarity of culture and geography, quality of education and a livable country [3].

The doors of the universities in Turkey are open not only for Afghan students but also for anyone who would like to receive education in the country. This process started with the Foreign Student Examinations (YÖS) for those who want to receive education by their own means in 1981 . Treaties were signed in 1992 with Turkic Republics in order for students in the Turkic Republics that became independent after the separation of the Soviet Union in 1989 to receive education in Turkey, and the Examinations for Turks Abroad and Related Communities (TCS) started. In this context, the "Great Student Project" started by Turkey could be considered as an important step in terms of new policies for the Turkish world and strengthening the position of the education sector in scope of these policies [4].

Every year, TCS is applied by the Center for Student Selection and Placement (ÖSYM) in Azerbaijan, Kazakhstan, Kyrgyzstan, Turkmenistan, Tajikistan and Tatarstan to select students who will attend higher education in Turkey. Additionally, foreign students come to Turkey through institutions such as the Islamic Development Bank, the Turkish Religious Foundation and similar organizations. Today, the number of foreign 
students who are in Turkey for education has reached 60642 [1].

This mobility of students with different citizenships both in Turkey and in the world naturally brought about various socio-cultural and economic problems in addition to problems related to language and education [3]. Studies with foreign students revealed that these students experienced loneliness, maladaptation, and cultural and psychological problems $([5,6]$. Yang (2006), in their study with 12 Chinese students studying in the United Kingdom, found that the most significant problem experienced by these students was socio-cultural adaptation [6]. Sandhu (1995) found that cultural differences and being away from home are significant sources of stress for students with different nationalities [7]. Berry (1997) defined this situation as an acculturation stress experienced constantly by foreign students [8]. Moreover, the problems that need to be overcome by foreign students include accommodation, food, health, climate, transportation and homesickness [9].

Considering the relevant studies, the cultural and psycho-social issues of foreign students are important to an extent that should not be ignored. Therefore, it is hoped that this study will make a significant contribution to the literature.

\subsection{Objective of the Study}

While the tools of communication and transportation in our time seem to be advanced, the lifestyle of today's people, migration, opening up to different geographies and culture bring about harmony and adaptation problems. Studying abroad and coming from a different geography and culture involves various difficulties by itself. Universities in Turkiye, has accelerated its efforts to serve the youth of the world not only their own citizens.

Having an internationalization or such a mission makes it inevitable to provide quality service to the students that it will serve by recognizing different aspects of them. This issue motivated us to investigate the cultural and psycho-social problems of Afghan students who come from different geography and culture to improve the adaptation and educational achievements. In accordance with this purpose the following topics have been examined in order to reveal the cultural and psycho-social problems of Afghan students in particular:
- Human Affairs
- Accommodation and Food Problems
- Clothing
- Psychological Problems
- Social Problems

\section{Materials and Methods}

\subsection{Method}

\subsubsection{Research Model}

In-depth interviewing research design, one of the qualitative research methods, has been applied in the research. In-depth interviewing is a data gathering technique that covers all dimensions of the studied subject, can be asked more open-ended questions, enables detailed answers to be received, and allows the collection of information face to face. The feelings, knowledge, experience and observations of the person can be reached through interview [11].

\subsubsection{Study Design and Sample}

According to the 24.12.2016 data of the Office of International Programs under the Registrar's Office of Uşak University, 50 registered Afghan students attended the university in different faculties in the academic year of 2015-2016, including 10 in the language preparation phase and 40 on the undergraduate level [11]. The sample of the study consisted of 10 Afghan students who attended different faculties of Uşak University in the academic year of 2015-2016. In this study, interviews were held with 2 female and 8 male students from difficult faculties on a voluntary basis. The participants were determined on a voluntary basis by purposive sampling. The descriptive characteristics about sampling are shown in Table 1.

Table 1. Distribution of Afghan Students in Terms of Their Sex, Age, Marital Status, and the Faculty They Were Enrolled in

\begin{tabular}{|c|c|c|c|c|c|c|c|}
\hline & 1 & 2 & 3 & 4 & 5 & 6 & 7 \\
\hline Sex & Male & Female & & & & & \\
\hline $\mathrm{n}$ & 8 & 2 & & & & & \\
\hline Age & 20 & 22 & 24 & 25 & & & \\
\hline $\mathrm{N}$ & 3 & 3 & 1 & 3 & & & \\
\hline Department & Economics & Economics & Construction & Business & $\begin{array}{l}\text { Public } \\
\text { Admin. }\end{array}$ & $\begin{array}{l}\text { Mechanical } \\
\text { Eng. }\end{array}$ & Health \\
\hline $\mathrm{n}$ & 2 & 1 & 2 & 1 & 1 & 1 & 2 \\
\hline Class level & 2nd year & 3rd year & & & & & \\
\hline $\mathrm{n}$ & 6 & 4 & & & & & \\
\hline Accommodation & Dorm & $\begin{array}{c}\text { Rented } \\
\text { apartment / alone }\end{array}$ & $\begin{array}{l}\text { Rented apartment / } \\
\text { with roommates }\end{array}$ & With family & & & \\
\hline $\mathrm{n}$ & 2 & 0 & 8 & 0 & & & \\
\hline Close relative & Yes & No & & & & & \\
\hline $\mathrm{n}$ & 4 & 6 & & & & & \\
\hline
\end{tabular}




\subsubsection{Data Collection and Analysis}

The data of the study were collected through semi-structured interview forms containing the concepts. The questions were formed by the researchers by receiving opinions of experts working in the field of psychological counseling.

This study used the method of semi-structured interviewing to collect the data, as per the statement by [12], it makes it easier to obtain realistic and in-depth information and provides flexibility of analysis. The interviews were held in the office of the researchers in their presence. It was considered that the participants might have difficulty in understanding and speaking Turkish, so, the questions were attempted to be made as simple and plain as possible, and the students were provided with enough time to prevent them from answering superficially. The interviews lasted about 25-30 minutes on average. The sentences used by the students were presented as direct quotes in the findings section of the study, and analyses were made. The Afghan students who participated in the study were coded as S-1, S-2, S-3, S-4, S-5, S-6, S-7, S-8, S-9 and S-10. The theme-formation process was replicated by another expert. The similarity of themes was confirmed this way.

Table 2. The Theme and Category Model Formed Based on Descriptive Analysis

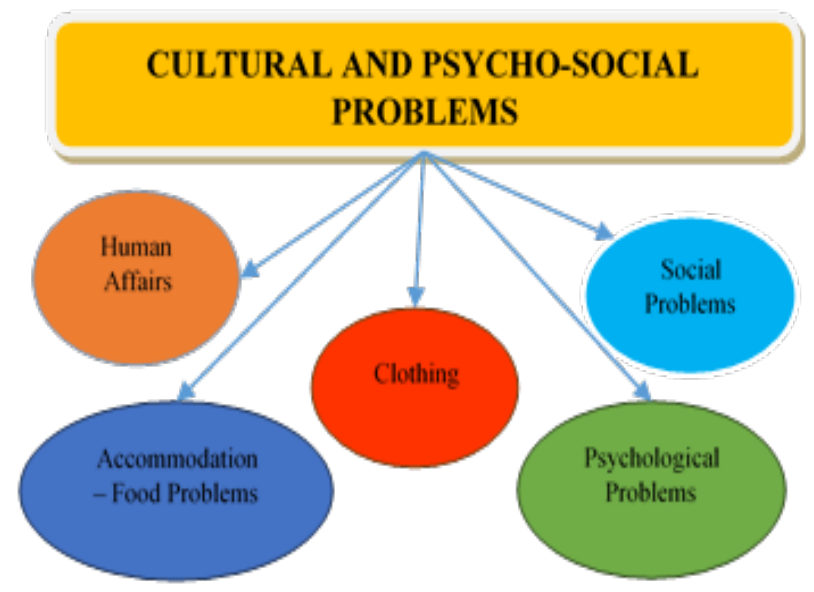

\section{Findings and Comments}

Table 3. Findings and Comments on Human Affairs

\begin{tabular}{|c|c|}
\hline \multicolumn{2}{|r|}{ HUMAN AFFAIRS } \\
\hline \multicolumn{2}{|c|}{$\begin{array}{l}1 \text { - Do you have a problem with Turkish? } \\
2 \text { - Do you have a close friend in the period you have been living in Turkey? } \\
3 \text { - To what extent the representatives and agencies of Afghanistan in Turkey are interested in you? }\end{array}$} \\
\hline Student & Some Responses by the Students \\
\hline S-1 & $\begin{array}{l}\text { - I can usually communicate with foreign friends more easily. I have no communication problems. No agencies of } \\
\text { ours contacted us, }\end{array}$ \\
\hline S-2 & I did not experience language issues, I have relatives in Turkey, no agencies of ours contacted us. \\
\hline S-3 & $\begin{array}{l}\text { - I have no problem with the Turkish language, I made good friends in Turkey and no agencies of ours ever } \\
\text { contacted us, }\end{array}$ \\
\hline S-4 & $\begin{array}{l}\text { - I have some problems with the language, I made new friends in Turkey and there is no one contacting us from our } \\
\text { agencies, }\end{array}$ \\
\hline S-5 & $\begin{array}{l}\text { - I partly have problems with the Turkish language, I made new friends in Turkey and no agencies of ours ever } \\
\text { contacted us, }\end{array}$ \\
\hline S-6 & $\begin{array}{l}\text { - I partly have problems with the Turkish language, I made new friends in Turkey and no agencies of ours ever } \\
\text { contacted us, }\end{array}$ \\
\hline S-7 & $\begin{array}{l}\text { - I have no problem with the Turkish language, I could not make new friends in Turkey. Actually, no one in our } \\
\text { agencies contacted us, }\end{array}$ \\
\hline S-8 & I have no problem with the Turkish language or making friends, no one contacted us from our agencies, \\
\hline S-9- & $\begin{array}{l}\text { - I have no problem with the Turkish language, I do not have many friends in Turkey. No one contacted us from our } \\
\text { agencies, }\end{array}$ \\
\hline S-10- & $\begin{array}{l}\text { - I am experiencing problems with the Turkish language now. I could not make new friends in Turkey. No one in } \\
\text { our agency was interested, }\end{array}$ \\
\hline
\end{tabular}

As seen in Table 3 about human affairs, S-4, S-5, S-6 and S-10 stated that they experienced some problems, and the other students stated that they did not have a problem with the language. S-7 and S-10 stated that they could not make friends in Turkey yet, while most students said the agencies of Afghanistan in Turkey never contacted them. 
Table 4. Findings and Comments on Accommodation and Food

\begin{tabular}{|c|c|}
\hline \multicolumn{2}{|r|}{ ACCOMMODATION AND FOOD } \\
\hline \multicolumn{2}{|c|}{$\begin{array}{l}\text { 4- Where are you accommodated? Do you experience problems with your accommodations? } \\
\text { 5- In which part or space do you eat? }\end{array}$} \\
\hline Student & Some Responses by the Students \\
\hline S-1 & - I am experiencing problems with accommodation and food \\
\hline $\mathrm{S}-2$ & - I did not experience accommodation or food problems as I came with state scholarship. \\
\hline S-3 & $\begin{array}{l}\text { - I am staying at a rented apartment with students from Afghanistan. I have financial problems. We usually prepare } \\
\text { the food at home }\end{array}$ \\
\hline S-4 & - I have accommodation problems and we prepare the food at home. \\
\hline S-5 & $\begin{array}{l}\text { - In terms of accommodation, rents are too expensive. We sometimes eat out and sometimes prepare the food at } \\
\text { home. }\end{array}$ \\
\hline S-6 & - I occasionally have problems about accommodation. \\
\hline S-7 & - I experience problems about accommodation and food. \\
\hline S-8 & - About accommodation and food, rent prices are high and I experience problems. \\
\hline S-9- & - I am staying at a rented apartment with friends, we cook at home and I do not have a problem with food. \\
\hline S-10- & - I am staying at a rented apartment with friends, we cook at home and I do not have a problem with food. \\
\hline
\end{tabular}

S-1, S-4, S-5, S-6, S-7 and S-8 stated that they had problems in terms of accommodations. They stated that rents are too expensive; they sometimes ate out and sometimes cook at home. Two students (S-1 and S-7) said they had problems with food, and they solved these problems by preparing food at home by themselves. Considering the responses, preparation of food by the students themselves means they had problems about the food.

Table 5. Findings and Comments on Clothing

\begin{tabular}{|c|c|l|}
\hline \multicolumn{5}{|l|}{ CLOTHING } \\
6- Is there a lot of difference between the clothing in Turkey and your country? \\
7- Could you use your traditional clothing comfortably in Turkey? \\
\hline Student & & \multicolumn{1}{c|}{ Some Responses by the Students } \\
\hline S-1 & $\bullet$ & I have no problem about clothing. \\
\hline S-2 & $\bullet$ & There are clothing differences, but I do not experience problems. \\
\hline S-3 & $\bullet$ & Yes, there are a lot. We cannot wear our traditional clothes comfortably because they attract must attention. \\
\hline S-4 & $\bullet$ & Yes, there is a difference, so, we are not comfortable in terms of clothing. \\
\hline S-5 & $\bullet$ & $\begin{array}{l}\text { There is a difference in clothing. We do not wear jeans or trousers in our country this much. We cannot wear our } \\
\text { traditional clothes as they seem strange for the people here. }\end{array}$ \\
\hline S-6 & $\bullet$ & There is a difference in clothing. We cannot wear our traditional clothes as they seem strange for the people here. \\
\hline S-7 & $\bullet$ & There is not much difference in clothing. We use our traditional clothes only on special occasions here. \\
\hline S-8 & $\bullet$ & There is a lot of difference in clothing. I cannot use our traditional clothes comfortably here. \\
\hline S-9- & $\bullet$ & There is a lot of difference in clothing. We cannot use our traditional clothes comfortably. \\
\hline S-10- & $\bullet$ & There is a lot of difference in clothing. We use our traditional clothes only on special occasions here. \\
\hline
\end{tabular}

Most students stated that there are differences between Turkey and the country they came from in terms of clothing. However, only two students (S-7 and S-10) said there is a little difference between the countries. All students except two (S-1 and S-2) stated that they were not comfortable wearing their national and traditional clothes, and they wore them only on special occasions. 
Table 6. Findings and Comments on Psychological Problems

\begin{tabular}{|c|c|}
\hline & PSYCHOLOGICAL PROBLEMS \\
\hline $\begin{array}{l}8 \text {-What do } \\
\text { 9-Who do } \\
10 \text { - Do you } \\
11 \text { - In what } \\
\text { 12-Did you } \\
\text { was provid } \\
\text { 13- What e } \\
14 \text { - Would }\end{array}$ & $\begin{array}{l}\text { do when you have a problem? Which methods do you use to get rid of your problem? } \\
\text { ontact first when you have a problem? } \\
\text { health issues or complaints? } \\
\text { ect do you find it the most difficult to adapt to university life? } \\
\text { nd any orientation (counseling) program since you arrived in Turkey? (whether an adaptation or orientation program } \\
\text { the students about the university and the city by the university, faculty or department) } \\
\text { tations did you have before coming to Turkey and how much of these expectations were met? } \\
\text { come to Turkey if you had a chance to reconsider? }\end{array}$ \\
\hline Student & Some Responses by the Students \\
\hline S-1 & $\begin{array}{l}\text { - When I get bored, I read a book. If I have a problem, I share it with Afghan friends. I rarely have health issues. I } \\
\text { experience loneliness as I am far from my family. I joined the orientation program of the university. I cannot say } \\
\text { that the university met all of my expectations. }\end{array}$ \\
\hline $\mathrm{S}-2$ & $\begin{array}{l}\text { - I read a book when I am bored. If I have a problem, I share it with close Afghan and Turkish friends. I rarely } \\
\text { experience health issues. I joined the orientation program by the dormitory. I cannot say that the university met } \\
\text { all of my expectations. }\end{array}$ \\
\hline S-3 & $\begin{array}{l}\text { - I play games when I am bored and sometimes go out with friends. If I have problem, I call my family and share } \\
\text { it with them. I experience health problems sometimes (psychologically). I attended no counseling programs. I } \\
\text { cannot say that the university met all of my expectations. }\end{array}$ \\
\hline S-4 & $\begin{array}{l}\text { - When I get bored, I prefer to go out and visit places. When I have a problem, I share it firstly with my cousin } \\
\text { who is a student in Uşak. No counseling was provided to us since I came to Uşak. I cannot say that the university } \\
\text { met all of my expectations. }\end{array}$ \\
\hline S-5 & $\begin{array}{l}\text { - When I get bored, I exercise or smoke. When I have a problem, I shared with an older brother of mine living in } \\
\text { Turkey. In terms of health, I sometimes feel mentally bored and this is reflected on my grades. No counseling } \\
\text { was provided to us since I came to Uşak. I cannot say that the university met all of my expectations. }\end{array}$ \\
\hline S-6 & $\begin{array}{l}\text { - When I get bored, I meet my classmates. If I have a problem, I firstly talk to my supervisor and then my friends. } \\
\text { I sometimes experience health problems. I have problems with classes and no counseling was provided to me. I } \\
\text { cannot say that the university met all of my expectations. }\end{array}$ \\
\hline S-7 & $\begin{array}{l}\text { - I talk to my friends when I get bored. I am not experiencing health problems. I attended a counseling program by } \\
\text { the university when I started studying. I could say that the university met } 30 \% \text { of my expectations. Despite this, I } \\
\text { would choose this university again. }\end{array}$ \\
\hline S-8 & $\begin{array}{l}\text { - I meet my friends and read a book when I get bored. If I experience a problem, I share it with my friends. I am } \\
\text { not experiencing health problems. I experience problems about the university mostly in terms of transportation I } \\
\text { did not attend a counseling program by the university when I started. The university is close to my expectations. }\end{array}$ \\
\hline S-9- & $\begin{array}{l}\text { - I draw when I get bored or consult my roommate first if I have a problem. I do not experience health issues, but I } \\
\text { have financial issues. I did not attend any counseling program. I could say that the university my } 40 \% \text { of my } \\
\text { expectations. Despite this, I would choose this university again, not for the city but for the department. }\end{array}$ \\
\hline S-10- & $\begin{array}{l}\text { - I pray and read a book when I am bored, and firstly contact my family when I have a problem. I did not } \\
\text { experience a health problem, but I am having difficulty understanding the classes. No, I did not attend such } \\
\text { program. The university meets a part of my expectations. }\end{array}$ \\
\hline
\end{tabular}

Considering the responses about the psychological problems, it is seen that all students experienced issues. These students were asked about what they did, and whom and how they contacted when they had issues. As a response to this question, S-1, S-2 and S-8 said they read a book, S-3 said he played games, S-4, S-6, S-7 and S-8 said they went out and met friends, S-5 said he exercised or smoked, S-9 said she drew, and S-10 said she prayed. All the participants stated that they experienced issues in this matter and resorted to their supervisor at the school, friends, spiritual support and methods and habits unique to themselves to cope with these problems. For example, S-10 said she prayed.

About the question on the health issues experienced by the students, S-1, S-3, S-5 and S-6 said they experienced issues and these issues were loneliness and mental issues as they are far from their families.

S-1 and S-7 stated that they joined the introduction and orientation program carried out by the university when they first arrived and S-2 said he attended the orientation program carried out by the dormitory, while the other students stated that they attended no programs or received no services related to orientation or counseling. S- 8 stated that the university he was studying at was close to his expectations, that is, it met his expectations. The other students who participated in the study expressed their opinions as that the university partly met their expectations. S-9 said she could choose the university again, not regarding the city but about the department. 
Table 7. Findings and Comments on Social Problems

SOCIAL PROBLEMS
\begin{tabular}{|}
\hline \multicolumn{1}{|l|}{ 15- What are your thoughts about your own future? (Your job and career plans) } \\
16- Are there any other issues that trouble you outside the university? \\
17- What are your problems about the city you are studying in? \\
18- Are there any other issues you would like to declare other than those asked in these questions? \\
\hline Student & \multicolumn{1}{c|}{ Some Responses by the Students } \\
\hline S-1 & $\bullet$ & $\begin{array}{l}\text { I am optimistic about subjects related to the future, but I experience financial problems while studying. The } \\
\text { university integrates us with the city. }\end{array}$ \\
\hline S-2 & $\bullet$ & I am optimistic about future matters. The university integrates us with the city. \\
\hline S-3 & $\bullet$ & $\begin{array}{l}\text { I believe I will have a bright future when I graduate from my degree. The main problem I have outside the } \\
\text { university is accommodation. I could say accommodation and transportation are the problems I have regarding } \\
\text { the city I live in. }\end{array}$ \\
\hline S-4 & $\bullet$ & I am hopeful about the future. \\
\hline S-5 & $\bullet$ & $\begin{array}{l}\text { I am optimistic about the future. I think it is a problem that Uşak has traffic issues and no opportunities of } \\
\text { part-time jobs for students. I experience a general problem with adaptation and acclimatization. }\end{array}$ \\
\hline S-6 & $\bullet$ & $\begin{array}{l}\text { I do not currently have an opinion about the future. I experience a general problem with adaptation and } \\
\text { acclimatization to Uşak. }\end{array}$ \\
\hline S-7 & $\bullet$ & $\begin{array}{l}\text { I am currently optimistic about the future. It would be nice to have opportunities to work in Uşak. I am having } \\
\text { some financial difficulties. }\end{array}$ \\
\hline S-8 & $\bullet$ & I am currently optimistic about the future. \\
\hline S-9- & $\bullet$ & I am currently optimistic about the future. I miss my family. I do not have problems about the city I live in. \\
\hline S-10- & $\bullet$ & I am currently optimistic about the future. I have no problems about Uşak. \\
\hline
\end{tabular}

Considering the opinions of the students who participated in the study on their future, only S-6 said he did not have an opinion about the future, but all the other students said they were optimistic about it. The main problems experienced by the students outside the university were accommodation, transportation financial issues, adaptation and homesickness. They did not have any other problem regarding the city they lived in.

\section{Discussion and Conclusions}

In today's world, internationalization is a significant issue that is focused on socially and economically for all developed and developing countries. Through their activities and economic practices, countries are in an effort to get the largest share from international mobility. Among all these processes, Turkey is a country which wants to take on an active role in the process of internationalization with its geopolitical position, history and cultural heritage [13]. In this context, Turkey has entered a process of internationalization by communicating to the countries and nations in its surroundings or those it is in collaboration with that it thought would contribute to benefiting in the long term. This communication should be in the form of higher education mobility rather than buying and selling goods. Additionally, this higher education mobility should be considered as a good instrument for Turkey to strengthen its cultural and historical relations with countries which are historically close to Turkey like Afghanistan.

Mobility of international students and mutual correspondence with countries and cultures are considered to be a significant foreign policy and public diplomacy tool as they increase collaboration and solidarity [14]. In the last two decades, universities have become both the playground and the player of the global economic market [17]. This transformation made universities a part of economic policy rather than social policy. International students are the most important part of this market. The current number of international students worldwide which is close to three million naturally brings about various problems [15]. Therefore, this study aimed to inspect and reveal the cultural and psycho-social problems experienced by students of Afghanistan citizenship studying in Turkey.

As a result of the interviews with the student, the following results were reached:

Human Affairs: Most students stated that they had no problem learning and using the Turkish language. The study by Gülnar and Balci (2010) revealed that international university students leaned towards adapting to Turkish culture while keeping their own cultural traditions [16].

Accommodation, Food and Clothing: It was found that most of the participants had problems about these issues. The results of the study by Kıroğlu (2010) with international students support our results. There are several studies in the literature which reported that international students experienced problems in issues like accommodation [3], homesickness and food [18, 9, 7]. The most important factor influential on international students' feelings of being ostracized or experiencing prejudice is the cultural and geographical 
proximity/distance of the country they arrived in $[19,20]$. While the students experienced problems in terms of health, they listed these problems as feelings of loneliness because of their distance from their families and mental issues. Kıroğlu (2010) reported that almost all international students felt homesick [3].

Clothing: Most of the participants stated that there are differences between Turkey and the country they came from in terms of clothing. It was seen that the participants did not feel comfortable to wear their national and traditional clothes in Turkey.

Psychological Problems: Almost all students experienced problems. These students stated that, when they had issues, they read books, played games, went out to meet their friends, exercised, smoked, drew and prayed. Moreover, all participants stated that they experienced issues in this matter, and they resorted to close relatives, supervisors at the school, friends, spiritual support and methods and habits unique to themselves to cope with this situation. For example, S-10 stated that she prayed. Some students said they experienced health issues and they felt loneliness and mental problems as they were far from their families.

Only two students (S-1 and S-7) said they participated in introduction and orientation programs issued by the university regarding adaptation to university life. While one student (S-2) said he attended the orientation program carried out by the state dormitory he stayed in, the others said they did not attend any orientation or counseling programs or received any related service. Most participants said the university they studied at met their expectations partly. Only one student (S-9) said she would chose this university again based on the department and not the city, while the others did not respond to this question. It is understood that universities need to create and provide counseling and adaptation programs for all students in general and international students in particular. This is because these students are coming from different geographies, countries and cultures. The is a necessity for minimizing issues that arise from this difference and making adaptation easier. Karaoğlu (2007) found that behaviors of adaptation decreased as the cultural differences increased, and the levels of students to adopt the culture they live in increased as the differences disappeared [21]. This situation naturally affects the academic success of the students at their university positively or negatively. Therefore, counseling to be provided to these students becomes important.

Social Problems: Considering the opinions of the students who participated in the study on their own future, it was found that all were optimistic about the future and they did not experience problems about the city they lived in. Individuals' objectives for themselves make it easier for them to make sense of their lives and lead a more positive life [22]. Therefore, having objectives about life increases their motivation levels in many aspects. Students with life objectives have high motivations in the education process. This is because there is a significant relationship between the motivation and success levels of students in education processes [23].

Student dormitories that operate in Turkiye, should allocate additional quotas to foreigners and the accommodation, nutrition and related needs of these students should be met in their dormitories. Special days can be organized for the celebration of the national, cultural and religious days of Afghan students, and two cultures can be recognized and blended together. Especially, social consciousness should be established for the social acceptance of foreign students in the university, the residence and the city where they live and in this way the clothing problem of Afghan students can be solved.

In overcoming psychological problems, administrators and consultants who are interested in foreign students in universities are more in charge. Guidance teacher of Afghan students provide guidance especially in the first year when foreign students come to school about adaptation, coalescence and communication in addition to academic guidance. It will be effective and useful for the Afghan students to be guided by the academic advisors in order to receive support from the university psychologist when necessary during the years of teaching.

\section{REFERENCES}

[1] Meb,

http://sgb.meb.gov.tr/meb_iys_dosyalar/2016_03/1802400 9 meb_istatistikleri_orgun_egitim2015_2016.pdf, $0 \overline{7} .08 .2017$

[2] Şapolyo, E. B., (1960). Türkiye Cumhuriyeti Tarihi, Ahmet Halit Yaşaroğlu Kitapçıllk ve Kâğgtçıllk Ltd. Şti. İstanbulAnkara Caddesi, 121, Neşriyat Sayısı No:804

[3] Polat, H. A. (2011). Türkiye Cumhuriyeti Tarihi, Editörler: AKANDERE, Osman, SEMIZ, Yaşar, Eğitim Akademi Yayını,

[4] Kıroğlu, K. Kesten, A., Elma, C. (2010). Türkiye'de Öğrenim Gören Yabancı Uyruklu Lisans Ögrrencilerinin Sosyo- Kültürel ve Ekonomik Sorunlart, Mersin Üniversitesi Eğitim Fakültesi Dergisi, Cilt 6, Sayı 2, Aralık 2010, ss.26-39./Mersin University Journal of the Faculty of Education, Vol. 6, Issue 2, December 2010, pp.26-39.

[5] Kavak, Y. Baskan, G., A., (2001). Türkiye'nin Türk cumhuriyetleri, Türk ve akraba topluluklarına yönelik eğitim politika ve uygulamaları. Hacettepe Üniversitesi Eğitim Fakültesi Dergisi, 20: 92 -103.

[6] Tomich, P. McWhirter, J. J., and King, W. E. (2000). International student adaptation: Critical variables. University responses. London: Praeger.

[7] Bek, H., (2014). An Analysis On Loneliness Level Of Afghani University Students In Turkey In Respect Of Some Variables, Mevlana International Journal of Education.; 


\section{4(2)132-138 DOI: 10.13054/mije.14.01.4.2}

[8] Yang, H. (2006). Understanding experiences of being a Chinese overseas student in the United Kingdom: Learning, culture and identity. In "Ways of knowledge and doing", Student Conference, University of Birmingham.)

[9] Sandhu, D. S. (1995). An examination of the psychological needs of the international student: Implications for counseling and psychotherapy. International Journal of Advancement of Counseling, 17, 229-239

[10] Berry, J. W. (1997). Immigration, acculturation and adaptation. Applied Psychology, 46(1), 5-34

[11] Tekin, H., H., (2006), "Nitel Araştırma Yönteminin Bir Veri Toplama Tekniği Olarak Derinlemesine Görüşme", Sosyoloji Dergisi, Say1: 13, ss.101-116.

[12] Uşak Üniversitesi (2016). Uşak Üniversitesi Rektörlüğü öğrenci işleri daire başkanlığına Uluslararası Öğrenci Ofisi, [Uşak University Rectorate Student Office Department International Student Office], 24.12.2016

[13] Yildırım, A. Şimşek, H. (2006). Sosyal Bilimlerde Nitel Araştırma Yöntemleri. Ankara: Seçkin Yayıncılık

[14] Şimşek, B. Bakır, S. (2016). Uluslararası Öğrenci Hareketliliği ve Atatürk Üniversitesinin Uluslararasilaşma Süreci, A. Ü. Türkiyat Araştırmaları Enstitüsü Dergisi [TAED] 55, Erzurum: s. 509-542

[15] Özoğlu, M., Gür, B., Coşkun İ., (2012). Küresel eğilimler ışığında Türkiye'de uluslararası öğrenciler, Ankara. Seta Yayınları.
[16] Currie, J., De Angelis, R., De Boer, H., Huisman, J., and Lacotte, C. (2003). Globalizing Practices and University Responses: European and Anglo-American Differences.

[17] De Wit, H. (2002). Internationalization of higher education in the United States of America and Europe: A Historical, Comparative, and Conceptual Analysis

[18] Gülnar, B. ve Balc1, S. (2010). Televizyon izleme motivasyonları ve kültürleşme: Yabancı uyruklu Üniversite Öğrencileri Üzerine Bir Araştırma/Television Viewing Motives and Acculturation: A Survey On Foreign University Students, Selçük Üniversitesi Türkiyat Araştirmalari Dergisi, 28. Sayı, 447-483

[19] Açıalın, A., Demirel, Ö. ve Önsoy, R. (1996). Türkiye’de yükseköğrenim gören Türk cumhuriyetleri öğrencilerinin sorunları. Ankara: Pegem A Yayıncılık.

[20] Pedersen, P. B. (1991). Counseling international students. Counseling Psychologist, 19, 10-58.

[21] Sodowsky, G. R., and Plake, B. S. (1992). A study of acculturation differences among international people and suggestions for sensitivity to within-group differences. Journal of Counseling and Development, 71, 53-59.

[22] Karaoğlu, F. (2007). Yabancı uyruklu öğrencilerde uyma davranışı:TÖMER örneği. Yayımlanmamış yüksek lisans tezi, Gazi Üniversitesi, Sosyal Bilimler Enstitüsü, Ankara.

[23] Eryılmaz, A., (2012). Amaçlar: Ruh ve Beden Sağlı̆̆ını Korumanın Önemli Bir Aracı, Goals: A Significant Tool for Protection of Mental and Physical Health, Psikiyatride Güncel Yaklaşımlar-Current Approaches in Psychiatry. 